\title{
Pajanan Partikulat Debu Kapur dan Faktor Risiko Pekerja dengan Kejadian ISPA: Sebuah Literature Review
}

\author{
Exposure of Particulate Lime Dust and Worker Risk Factors \\ with the Incidence of ARI: A Literature Review
}

\author{
Mirza Fathan Fuadi, Onny Setiani dan Yusniar Hanani Darundiati \\ Magister Kesehatan Lingkungan, Fakultas Kesehatan Masyarakat, Universitas Diponegoro \\ E-mail: Mirzaff@gmail.com
}

\begin{abstract}
A B S T R A C T / A B S T R A K
Limestone mining is an industry that produces pollutants in the air. The pollutants produced from the lime mining industry are dust and gas particles. The resulting lime dust can harm the health of workers. ARI is a respiratory disease that attacks lime mining workers. ARI does not only occur due to exposure to lime dust, there are several risk factors for workers that can cause ARDs. This study aims to determine the exposure to lime dust and the risk factors for workers with the incidence of ARI. This research was conducted using the literature review method with a sample size of 16 journals. The results showed that $80 \%$ of the variables studied were significant or had a relationship with the incidence of ARI. From the review of the article, it is known that there is a period of work, use of PPE, age, history of disease and smoking habits. The most dominant risk factors that have a significant relationship with the incidence of ARI are the working period variable and the use of PPE.
\end{abstract}

Keywords: Lime mine, Lime dust, ARI.

\begin{abstract}
Tambang kapur merupakan salah satu industri yang menghasilkan polutan di udara. Polutan yang dihasilkan dari industri tambang kapur adalah partikel debu dan gas. Debu kapur yang dihasilkan dapat mengganggu kesehatan pekerjanya. ISPA adalah salah satu penyakit gangguan saluran pernapasan yang menyerang pekerja tambang kapur. ISPA tidak hanya terjadi akibat pajanan debu kapur, terdapat beberapa faktor risiko pekerja yang dapat menyebabkan terjadinya ISPA. Penelitian ini bertujuan untuk mengetahui pajanan debu kapur dan faktor risiko pekerja dengan kejadian ISPA. Penelitian ini dilakukan menggunakan metode literature review dengan besar sampel sebanyak 16 jurnal. Hasil menunjukkan variabel yang bermakna atau memiliki hubungan dengan kejadian ISPA diperoleh sekitar $80 \%$ dari beberapa variabel yang di teliti. Dari tinjauan artikel diketahui ada masa kerja, penggunaan alat pelindung diri (masker), usia, riwayat penyakit dan kebiasaan merokok. Faktor risiko yang paling dominan memiliki hubungan yang bermakna dengan kejadian ISPA adalah variabel masa kerja dan variabel penggunaan alat pelindung diri (masker).
\end{abstract}

Kata Kunci: Tambang kapur, Debu kapur, ISPA

\section{PENDAHULUAN}

Masalah pencemaran udara telah lama menjadi penyebab masalah kesehatan, terutama di negara-negara industri yang memiliki banyak pabrik dan kedaraan bermotor. ${ }^{1}$ Pencemaran udara juga telah menjadi fenomena yang biasa di beberapa negara khusunya di negara berkembang. Hal ini dikarenakan dari industri 
yang ada, masih banyak yang kurang memperhatikan mengenai pengendalian pencemaran udara. Salah satu industri yang menyebakan pencemaran udara adalah industri tambang kapur. Polutan yang dihasilkan dari industri tambang kapur yaitu partikel debu dan gas-gas hasil. Debu dan gas-gas yang disebabkan oleh proses pengolahan batu kapur berada di lingkungan kerja, hal ini akan berakibat tenaga kerja terpapar debu kapur dan gas-gas pada konsentrasi maupun ukuran yang berbeda-beda. ${ }^{2}$

Kondisi lingkungan kerja akan berpengaruh terhadap kesehatan pekerja. Debu yang terdapat pada lingkungan kerja, akan mengganggu produktivitas dan kesehatan. Pekerja yang sering terpajan debu berisiko untuk mengalami keluhan kesehatan, baik berupa penyakit infeksi maupun non infeksi. Suatu potensi bahaya di tempat kerja akan masuk dan terakumulasi di dalam tubuh dipengaruhi oleh lama paparan, dan kelangsungan paparan. Semakin lama pekerja tersebut terpapar oleh pajanan salah satunya yaitu pajanan partikel debu maka akan semakin banyak partikel debu yang terakumulasi di dalam tubuh.

Dampak pajanan bahan-bahan berbahaya seperti polutan udara ditempat kerja dan lingkungan terhadap kesehatan, akan mengakibatkan berbagai macam gangguan salah satunya menimbulkan gangguan saluran pernapasan (ISPA). Penyakit saluran pernapasan merupakan penyakit akibat kerja pada industri yang sering dijumpai di negara berkembang, prevalensinya bervariasi antara 2-20\%. ISPA disebabkan oleh lebih dari 300 jenis bakteri, virus, dan riketsia. Bakteri yang dapat menyebabkan ISPA antara lain dari genus Streptokokus, Stafilokokus, Hemofilus, Bordetela, Corinebakterium, dan Pneumokokus, sedangkan virus yang dapat menyebabkan ISPA antara lain dari golongan Pikornavirus, Herpesvirus, Miksovirus, Adenovirus, dan Mikoplasma. ${ }^{3}$

Gangguan saluran pernapasan terjadi secara bertahap atas proses akumulasi paparan yang masuk kedalam paru. Selain dari paparan lingkungan gangguan pada saluran pernapasan dapat juga di pengaruhi dari karakteristik pekerja itu sendiri. Karakteristik pekerja yang mempengaruhi terjadinya gangguan saluran pernapasan meliputi umur, jenis kelamin, riwayat pekerja menderita penyakit paru, lama pajanan, kebiasaan merokok, masa kerja, tingkat pendidikan pekerja dan penggunaan alat pelindung diri berupa masker. ${ }^{4}$ Oleh karena uraian diatas, penulisan literature review ini bertujuan untuk mengetahui pajanan debu kapur dan faktor risiko pekerja dengan kejadian ISPA.

METODE

Penelitian ini merupakan literature review. Literature review adalah metode penelitian yang merupakan ulasan kembali tentang topik tertentu yang menekankan pada pertanyaan tunggal yang telah dikenali secara sistematis, dinilai, dipilih dan disimpulkan menurut kriteria yang telah ditentukan sebelumnya berdasarkan bukti penelitian yang berkualitas tinggi yang relevan dengan pertanyaan penelitian. ${ }^{5}$ Sumber data penelitian ini berasal dari literatur yang diperoleh melalui internet berupa hasil penelitian ilmiah dari beberapa sumber. Pengambilan data dilakukan melalui searching internet dari google scholar dan science direct dengan kata kunci yang dimasukkan yaitu pencemaran udara debu kapur, dan determinan kejadian ispa terutama faktor pekerja.

Populasi dalam penelitian adalah penelitian dengan fokus faktor risiko pekerja dengan kejadian ISPA dari tahun 2016 sampai dengan tahun 2020 sebanyak 16 hasil penelitian yang bersumber dari publikasi ilmiah Biology Department, Kedokteran dan Parasitologi, Kedokteran dan Kesehatan Masyarakat, Kesehatan Lingkungan dan Kesehatan Masyarakat.

Pengambilan sampel dalam penelitian ini adalah non probability sampling dengan tehnik total sampling. Total sampling adalah tehnik pengambilan sampel dengan jumlah sampel sama dengan populasi. Besar sampel penelitian ini adalah 16 jurnal. Kriteria inklusi yang digunakan adalah:

1. Penelitian diterbitkan dalam rentang tahun 2016-2020

2. Memiliki tema penelitian tentang pencemaran udara debu kapur dan ISPA

3. Memiliki faktor risiko pekerja dengan kejadian ISPA yang bernilai signifikan

Didapatkan data kuantitatif yang selanjutnya dianalisis secara sistematis sehingga mendapatkan bahasan dan simpulan yang mewakili isi dari literature review. 
Literature Review yang digunakan berjumlah 16 dengan isi hubungan antara kadar debu kapur dan faktor risiko pekerja dengan kejadian infeksi saluran pernapasan akut (ISPA). Kemudian di klasifikasikan menjadi 2 klaster, yaitu pencemaran udara di tambang kapur dan faktor risiko pekerja terhadap kejadian ISPA. Sampel penelitian pada jurnal yang digunakan sebagai literature review bersifat nasional sehingga dapat merefleksikan permasalahan pencemaran debu kapur dan faktor risiko pekerja tambang kapur secara menyeluruh terhadap kejadian ISPA

HASIL

Identifikasi dan Sintesis Jurnal

Tabel 1. Tabel Hasil Sintesis Jurnal

\begin{tabular}{|c|c|c|c|c|c|c|}
\hline No. & Penulis & Tujuan & Desain & Sampel & Variabel & Hasil \\
\hline 1. & $\begin{array}{l}\text { Leni } \\
\text { Widdianti } \\
(2018)\end{array}$ & $\begin{array}{l}\text { Untuk mengetahui } \\
\text { faktor-faktor yang } \\
\text { berhubungan } \\
\text { dengan kasus } \\
\text { pernafasan } \\
\text { penyakit pada } \\
\text { pekerja tambang } \\
\text { kapur } \\
\text { Kecamatan } \\
\text { Buliide } \\
\text { Kabupaten Kota } \\
\text { Barat Provinsi } \\
\text { Gorontalo }\end{array}$ & $\begin{array}{l}\text { Cross } \\
\text { Sectional }\end{array}$ & $\begin{array}{l}\text { Tehnik } \\
\text { pengambilan } \\
\text { sampel yang } \\
\text { digunakan } \\
\text { adalah total } \\
\text { sampling yaitu } \\
\text { populasi yang } \\
\text { dijadikan } \\
\text { sampel } \\
\text { berjumlah } 185 \\
\text { responden }\end{array}$ & $\begin{array}{l}\text { Variabel dalam } \\
\text { penelitian } \\
\text { diantaranya: lama } \\
\text { bekerja, umur, } \\
\text { perilaku merokok, } \\
\text { masa kerja, dan } \\
\text { riwayat penyakit }\end{array}$ & $\begin{array}{lr}\text { Hasil penelitian } \\
\text { menunjukkan } \begin{array}{r}\text { terdapat } \\
\text { hubungan yang }\end{array} \\
\text { signifikan antara variabel } \\
\text { lama kerja, umur, } \\
\text { perilaku merokok dan } \\
\text { riwayat penyakit dengan } \\
\text { penyakit } \\
\text { pernafasan pada pekerja } \\
\text { tambang kapur di } \\
\text { Kecamatan } \\
\text { Kabupaten Kota Barat } \\
\text { Provinsi Gorontalo }\end{array}$ \\
\hline 2. & $\begin{array}{l}\text { Vio Febri } \\
\text { Ningtyas } \\
(2020)\end{array}$ & $\begin{array}{l}\text { Untuk mengetahui } \\
\text { munculnya } \\
\text { penyakit ISPA } \\
\text { dan faktor risiko } \\
\text { pajanan ISPA } \\
\text { pada masyarakat } \\
\text { yang tinggal di } \\
\text { lingkungan } \\
\text { penambangan } \\
\text { kapur batu } \\
\text { gamping Puger }\end{array}$ & $\begin{array}{l}\text { Case } \\
\text { Control }\end{array}$ & $\begin{array}{l}\text { Besar sampel } \\
\text { dalam } \\
\text { penelitian } \\
\text { sebanyak } 36 \\
\text { responden } \\
\text { yang terdiri } \\
\text { atas 18 kasus } \\
\text { dan } 18 \text { kontrol }\end{array}$ & $\begin{array}{l}\text { Variabel dalam } \\
\text { penelitian } \\
\text { diantaranya: usia } \\
\text { perilaku merokok, } \\
\text { riwayat penyakit, } \\
\text { jarak lokasi } \\
\text { tempat tinggal }\end{array}$ & $\begin{array}{lr}\text { Hasil } & \text { penilitian } \\
\text { menunjukkan } & \text { terdapa } \\
\text { hubungan } & \text { yang } \\
\text { signifikan antara varibel } \\
\text { riwayat penyakit dengan } \\
\text { kejadian ISPA }\end{array}$ \\
\hline 3. & $\begin{array}{l}\text { Lilis } \\
\text { Yunipah } \\
(2016)\end{array}$ & $\begin{array}{l}\text { Untuk mengetahui } \\
\text { karakteristik dan } \\
\text { lingkungan yang } \\
\text { berhubungan } \\
\text { dengan gangguan } \\
\text { fungsi paru pada } \\
\text { masyarakat yang } \\
\text { terpapar debu } \\
\text { kapur di Desa } \\
\text { Jatilaba } \\
\text { Kabupaten Tegal }\end{array}$ & $\begin{array}{l}\text { Cross } \\
\text { Sectional }\end{array}$ & $\begin{array}{l}\text { Tehnik } \\
\text { pengambilan } \\
\text { sampel yang } \\
\text { digunakan } \\
\text { adalah random } \\
\text { sampling yaitu } \\
\text { sampel } \\
\text { berjumlah } 54 \\
\text { responden }\end{array}$ & $\begin{array}{l}\text { Variabel dalam } \\
\text { penelitian } \\
\text { diantaranya: usia, } \\
\text { status gizi, } \\
\text { riwayat penyakit, } \\
\text { dan kadar debu } \\
\text { kapur }\end{array}$ & $\begin{array}{lr}\text { Hasil penelitian } \\
\text { menunjukkan } \\
\text { terdapat } \\
\text { hubungan yang } \\
\text { signifikan antara varibel } \\
\text { status gizi dan riwayat } \\
\text { penyakit dengan } \\
\text { gangguan fungsi paru }\end{array}$ \\
\hline 4. & $\begin{array}{l}\text { Yudi } \\
\text { Siswanto } \\
(2016)\end{array}$ & $\begin{array}{lr}\text { Untuk mengetahui } \\
\text { hubungan } & \text { antara } \\
\text { paparan } & \text { debu } \\
\text { dengan } & \text { derajat } \\
\text { obstruksi } & \text { dan } \\
\text { derajat restriksi } \\
\text { pada pekerja } \\
\text { penambang kapur } \\
\text { di Dusun Koro } \\
\text { Desa Pongpongan }\end{array}$ & $\begin{array}{l}\text { Cross } \\
\text { Sectional }\end{array}$ & $\begin{array}{l}\text { Tehnik } \\
\text { pengambilan } \\
\text { sampel yang } \\
\text { digunakan } \\
\text { adalah random } \\
\text { sampling yaitu } \\
\text { sampel } \\
\text { berjumlah } 30 \\
\text { responden }\end{array}$ & $\begin{array}{l}\text { Variabel dalam } \\
\text { penelitian } \\
\text { diantaranya: masa } \\
\text { kerja, lama kerja, } \\
\text { usia, dan status } \\
\text { kesehatan. }\end{array}$ & $\begin{array}{lr}\text { Hasil } & \text { penelitian } \\
\text { menjukkan } & \text { terdapat } \\
\text { hubungan } & \text { yang } \\
\text { bermakna antara lama } \\
\text { kerja dengan derajat } \\
\text { obstruksi dan derajat } \\
\text { restriksi pada pekerja } \\
\text { tambang kapur }\end{array}$ \\
\hline
\end{tabular}




\begin{tabular}{|c|c|c|c|c|c|c|}
\hline & & $\begin{array}{l}\text { Kecamatan } \\
\text { Marakurak } \\
\text { Kabupaten Tuban }\end{array}$ & & & & \\
\hline 5. & $\begin{array}{l}\text { Fahmita A } \\
(2019)\end{array}$ & $\begin{array}{l}\text { Untuk mengetahui } \\
\text { karakteristik } \\
\text { individu pekerja } \\
\text { dengan gangguan } \\
\text { faal paru pada } \\
\text { pekerja } \\
\text { pembakaran batu } \\
\text { kapur CV. Indah } \\
\text { Lestari } \\
\text { Kecamatan } \\
\text { Plumpang } \\
\text { Kabupaten Tuban }\end{array}$ & $\begin{array}{l}\text { Cross } \\
\text { Sectional }\end{array}$ & $\begin{array}{l}\text { Tehnik } \\
\text { pengambilan } \\
\text { sampel yang } \\
\text { digunakan } \\
\text { adalah total } \\
\text { sampling yaitu } \\
\text { populasi yang } \\
\text { dijadikan } \\
\text { sampel } \\
\text { berjumlah } 18 \\
\text { responden }\end{array}$ & $\begin{array}{l}\text { Variabel dalam } \\
\text { penelitian } \\
\text { diantaranya: usia, } \\
\text { masa kerja, } \\
\text { penggunaan APD, } \\
\text { kebiasaan } \\
\text { merokok, status } \\
\text { gizi dan riwayat } \\
\text { penyakit. }\end{array}$ & $\begin{array}{lr}\text { Hasil } & \text { penelitian } \\
\text { menunjukkan } & \text { bahwa } \\
\text { kadar debu yang terukur } \\
\text { di pembakaran batu } \\
\text { kapur } \quad \text { Kecamatan } \\
\text { Plumpang Kabupaten } \\
\text { Tuban berada di atas } \\
\text { NAB (Nilai Ambang } \\
\text { Batas) }\end{array}$ \\
\hline 6. & $\begin{array}{l}\text { Aris } \\
\text { Widodo } \\
(2017)\end{array}$ & $\begin{array}{l}\text { Untuk mengetahui } \\
\text { hubungan antara } \\
\text { lamanya bekerja } \\
\text { sebagai } \\
\text { penambang batu } \\
\text { kapur dengan } \\
\text { nilai } \mathrm{VO}_{2} \text { Maks di } \\
\text { daerah } \\
\text { Gunungkidul } \\
\end{array}$ & $\begin{array}{l}\text { Cross } \\
\text { Sectional }\end{array}$ & $\begin{array}{l}\text { Tehnik } \\
\text { pengambilan } \\
\text { sampel yang } \\
\text { digunakan } \\
\text { adalah total } \\
\text { sampling }\end{array}$ & $\begin{array}{l}\text { Varibel dalam } \\
\text { penelitian } \\
\text { diantaranya: masa } \\
\text { kerja, lama kerja } \\
\text { dan riwayat } \\
\text { penyakit }\end{array}$ & $\begin{array}{lr}\text { Hasil } & \text { penelitian } \\
\text { menunjukkan } & \text { ada } \\
\text { pengaruh hubungan } \\
\text { antara lamanya bekerja } \\
\text { sebagai penambang } \\
\text { kapur dengan nilai } \mathrm{VO}_{2} \\
\text { Maks, didapatkan nilai } \\
p=0,036\end{array}$ \\
\hline 7. & $\begin{array}{l}\text { Rahayu H, } \\
\text { Febi } \\
\text { Kolibu, } \\
\text { Ardaisyah } \\
\text { Tucunan } \\
\text { (2017) }\end{array}$ & $\begin{array}{l}\text { Untuk mengetahui } \\
\text { hubungan } \\
\text { karakteristik } \\
\text { individu dengan } \\
\text { kejadian ISPA } \\
\text { pada Pekerja } \\
\text { Tambang Kapur }\end{array}$ & $\begin{array}{l}\text { Cross } \\
\text { Sectional }\end{array}$ & $\begin{array}{l}\text { Tehnik } \\
\text { pengambilan } \\
\text { sampel yang } \\
\text { digunakan } \\
\text { adalah total } \\
\text { sampling yaitu } \\
\text { populasi yang } \\
\text { dijadikan } \\
\text { sampel } \\
\text { berjumlah } 40 \\
\text { responden }\end{array}$ & $\begin{array}{l}\text { Varibel dalam } \\
\text { penelitian } \\
\text { diantaranya: } \\
\text { umur, lama kerja, } \\
\text { masa kerja, dan } \\
\text { perilaku merokok }\end{array}$ & $\begin{array}{l}\text { Lama kerja memiliki } \\
\text { hubungan } \quad(p=0,836, \\
p>0,05) \text { dengan kejadian } \\
\text { penyakit ISPA pada } \\
\text { pekerja tambang kapur }\end{array}$ \\
\hline 8. & $\begin{array}{l}\text { Jein Frilly } \\
\text { Lantong, } \\
\text { Pitrah } \\
\text { Asfian, } \\
\text { Putra Eka } \\
\text { Meiyana } \\
(2016)^{6}\end{array}$ & $\begin{array}{l}\text { Untuk mengetahui } \\
\text { faktor yang } \\
\text { berhubungan } \\
\text { dengan kejadian } \\
\text { ISPA pada } \\
\text { pekerja } \\
\text { penggilingan padi } \\
\text { di Kabupaten } \\
\text { Kaloka Sulawesi } \\
\text { Tenggara }\end{array}$ & $\begin{array}{l}\text { Cross } \\
\text { Sectional }\end{array}$ & $\begin{array}{l}\text { Tehnik } \\
\text { pengambilan } \\
\text { sampel yang } \\
\text { digunakan } \\
\text { adalah random } \\
\text { sampling yaitu } \\
\text { sampel } \\
\text { berjumlah } 48 \\
\text { responden }\end{array}$ & $\begin{array}{l}\text { Varibel dalam } \\
\text { penelitian } \\
\text { diantaranya: } \\
\text { umur, jenis } \\
\text { kelamin, } \\
\text { kebiasaan } \\
\text { merokok, } \\
\text { penggunaan APD, } \\
\text { masa kerja }\end{array}$ & $\begin{array}{lr}\text { Hasil } & \text { penelitian } \\
\text { menunjukkan } & \text { terdapat } \\
\text { hubungan } & \text { yang } \\
\text { bermakna antara varibel } \\
\text { kebiasaan merokok, } \\
\text { penggunaan APD dan } \\
\text { masa kerja dengan } \\
\text { kejadian ISPA }\end{array}$ \\
\hline 9. & $\begin{array}{l}\text { Yudha Eka } \\
\text { Putra } \\
\text { Suwanto } \\
(2018)\end{array}$ & $\begin{array}{l}\text { Untuk } \\
\text { menganalisis } \\
\text { hubungan faktor } \\
\text { fisik lingkungan } \\
\text { dan karakteristik } \\
\text { individu dengan } \\
\text { keluhan } \\
\text { pernapasan }\end{array}$ & $\begin{array}{l}\text { Cross } \\
\text { Sectional }\end{array}$ & $\begin{array}{l}\text { Sampel } \\
\text { penelitian } 52 \\
\text { responden } \\
\text { diambil } \\
\text { menggunakan } \\
\text { sistem random } \\
\text { sampling }\end{array}$ & $\begin{array}{l}\text { Variabel } \\
\text { penelitian } \\
\text { diantaranya: masa } \\
\text { kerja, kebiasaan } \\
\text { merokok, } \\
\text { penggunaan APD, } \\
\text { jenis kelamin, } \\
\text { suhu, dan kadar } \\
\text { udara }\end{array}$ & $\begin{array}{l}\text { Hasil dalam penelitian } \\
\text { diperoleh hubungan yang } \\
\text { bermakna antara masa } \\
\text { kerja ( } p=1,000) \text {, } \\
\text { kebiasaan merokok }(p= \\
0,281) \text { dan penggunaan } \\
\text { APD ( } p=0,283) \text { dengan } \\
\text { keluhan pernapasan pada } \\
\text { pekerja }\end{array}$ \\
\hline 10. & $\begin{array}{l}\text { Yudha Eka } \\
\text { Putra } \\
(2017)\end{array}$ & $\begin{array}{l}\text { Untuk mengetahui } \\
\text { hubungan } \\
\text { penggunaan kayu }\end{array}$ & $\begin{array}{l}\text { Cross } \\
\text { Sectional }\end{array}$ & $\begin{array}{l}\text { Sampel } \\
\text { penelitian } 80 \\
\text { responden }\end{array}$ & $\begin{array}{l}\text { Variabel } \\
\text { penelitian } \\
\text { diantaranya:umur, }\end{array}$ & $\begin{array}{lr}\text { Hasil menunjukkan } \\
\text { bahwa variabel APD dan } \\
\text { merokok }\end{array}$ \\
\hline
\end{tabular}




\begin{tabular}{|c|c|c|c|c|c|c|}
\hline & & $\begin{array}{l}\text { bakar dalam } \\
\text { industri } \\
\text { pembakaran } \\
\text { genteng dengan } \\
\text { kejadian ISPA }\end{array}$ & & $\begin{array}{l}\text { diambil } \\
\text { menggunakan } \\
\text { model } \\
\text { consecutive } \\
\text { sampling }\end{array}$ & $\begin{array}{l}\text { APD, cerobong } \\
\text { asap dan merokok }\end{array}$ & $\begin{array}{l}\text { memilki hubungan } \\
\text { dengan kejadian ISPA }\end{array}$ \\
\hline 11. & $\begin{array}{l}\text { Muhamad } \\
\text { Yunus, } \\
\text { Widi } \\
\text { Raharjo, } \\
\text { dan Agus } \\
\text { Fitriangga } \\
(2020)\end{array}$ & $\begin{array}{l}\text { Untuk mengetahui } \\
\text { faktor-faktor yang } \\
\text { berhubungan } \\
\text { dengan kejadian } \\
\text { ISPA di PT.X }\end{array}$ & $\begin{array}{l}\text { Cross } \\
\text { Sectional }\end{array}$ & $\begin{array}{l}\text { Sampel } \\
\text { penelitian } 43 \\
\text { responden } \\
\text { diambil } \\
\text { menggunakan } \\
\text { sistem total } \\
\text { sampling }\end{array}$ & $\begin{array}{l}\text { Variabel } \\
\text { penelitian } \\
\text { diantaranya: } \\
\text { umur, jenis } \\
\text { kelamin, masa } \\
\text { kerja, penggunaan } \\
\text { APD dan peran } \\
\text { petugas kesehatan }\end{array}$ & $\begin{array}{l}\text { Diperoleh hasil terdapat } \\
\text { hubungan } \\
\text { bermakna antara } \\
\text { dang } \\
\text { dan penggunaan APD } \\
\text { dengan kejadian ISPA } \\
\text { pada pekerja PT.X }\end{array}$ \\
\hline 12. & $\begin{array}{l}\text { Resti } \\
\text { Fevria } \\
(2016)\end{array}$ & $\begin{array}{l}\text { Untuk mengetahui } \\
\text { kualitas udara di } \\
\text { daerah } \\
\text { penambangan } \\
\text { batu kapur Bukit } \\
\text { Tui Kota Padang } \\
\text { Panjang }\end{array}$ & & $\begin{array}{l}\text { Sampel dalam } \\
\text { penelitian } \\
\text { diantaranya: } \\
\text { kadar udara } \\
\text { ambien }\left(\mathrm{SO}_{2},\right. \\
\mathrm{CO}, \mathrm{NO}_{2}, \mathrm{O}_{3} \\
\text { dan TSP) }\end{array}$ & $\begin{array}{l}\text { Variabel } \\
\text { penelitian } \\
\text { diantaranya: kadar } \\
\text { udara ambien } \\
\left(\mathrm{SO}_{2}, \mathrm{CO}, \mathrm{NO}_{2},\right. \\
\mathrm{O}_{3} \text { dan TSP) }\end{array}$ & $\begin{array}{l}\text { Diperoleh hasil kadar } \\
\text { udara TSP dalam } \\
\text { penelitian melebihi baku } \\
\text { mutu kualitas udara } \\
\text { berdasarkan PP No. } 41 \\
\text { tahun 1999 tentang } \\
\text { pengendalian } \\
\text { pencemaran udara }\end{array}$ \\
\hline 13. & $\begin{array}{l}\text { Ibnu Sri } \\
\text { Fuqoha, } \\
\text { Ari } \\
\text { Suwondo } \\
\text { dan Siswi } \\
\text { Jayanti } \\
(2017)\end{array}$ & \begin{tabular}{lr}
\multicolumn{2}{l}{ Untuk mengetahui } \\
paparan & debu \\
kayu & dengan \\
kejadian & ISPA \\
pada & pekerja \\
mebel di Jepara
\end{tabular} & $\begin{array}{l}\text { Cross } \\
\text { Sectional }\end{array}$ & $\begin{array}{l}\text { Sampel } \\
\text { penelitian } 46 \\
\text { responden } \\
\text { diambil } \\
\text { menggunakan } \\
\text { sistem total } \\
\text { sampling }\end{array}$ & $\begin{array}{l}\text { Variabel } \\
\text { penelitian } \\
\text { diantaranya: } \\
\text { status gizi, umur, } \\
\text { masa kerja, lama } \\
\text { paparan dan } \\
\text { penggunaan APD }\end{array}$ & $\begin{array}{lr}\text { Hasil penelitian } \\
\text { menunjukkan } \\
\text { variabel umur, } \\
\text { kerja, dan } \\
\text { kesehatan } \\
\text { hubungan } & \text { status } \\
\text { signifikan } & \text { memiliki } \\
\text { kejadian ISPA } & \text { dengan } \\
\end{array}$ \\
\hline 14. & $\begin{array}{l}\text { Billy } \\
\text { Harnaldo } \\
\text { Putra, } \\
\text { Rifka } \\
\text { Afrani } \\
(2017)\end{array}$ & $\begin{array}{l}\text { Untuk mengetahui } \\
\text { hubungan masa } \\
\text { kerja, } \\
\text { pengetahuan, } \\
\text { kebiasaan } \\
\text { merokok dan } \\
\text { penggunaan } \\
\text { masker dengan } \\
\text { kejadian ISPA } \\
\text { pada pekerja batu } \\
\text { bata di Kelurahan } \\
\text { Manggis }\end{array}$ & $\begin{array}{l}\text { Cross } \\
\text { Sectional }\end{array}$ & $\begin{array}{l}\text { Sampel } \\
\text { penelitian } 46 \\
\text { responden } \\
\text { diambil } \\
\text { menggunakan } \\
\text { sistem total } \\
\text { sampling }\end{array}$ & $\begin{array}{l}\text { Variabel } \\
\text { penelitian } \\
\text { diantaranya: masa } \\
\text { kerja, kebiasaan } \\
\text { merokok, } \\
\text { penggunaan } \\
\text { masker dan } \\
\text { pengetahuan }\end{array}$ & 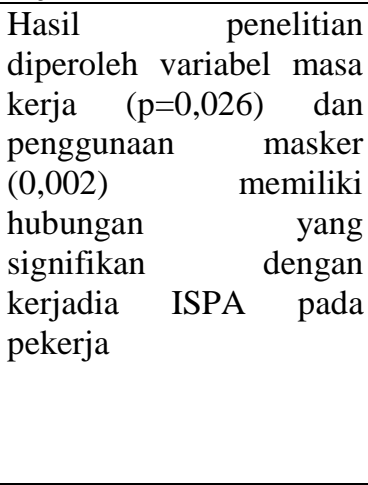 \\
\hline 15. & $\begin{array}{l}\text { Erka Dewi } \\
\text { Armaeni } \\
\text { dan } \\
\text { Noeroel } \\
\text { Widajati } \\
(2016)^{7}\end{array}$ & $\begin{array}{l}\text { Untuk mengetahui } \\
\text { hubungan anatara } \\
\text { karakteristik } \\
\text { responden dan } \\
\text { kadar debu } \\
\text { dengan status faal } \\
\text { paru pekerja di } \\
\text { CV. SRI MULYA } \\
\text { PUTRA } \\
\text { Kabupaten Tuban }\end{array}$ & $\begin{array}{l}\text { Cross } \\
\text { Sectional }\end{array}$ & $\begin{array}{l}\text { Jumlah } \\
\text { populasi } \\
\text { sebanyak } 78 \\
\text { dan sampel } \\
\text { penelitian } 23 \\
\text { responden } \\
\text { diambil } \\
\text { menggunakan } \\
\text { sistem total } \\
\text { sampling } \\
\end{array}$ & $\begin{array}{l}\text { Variabel } \\
\text { penelitian } \\
\text { diantaranya: } \\
\text { umur, jenis } \\
\text { kelamin, lama } \\
\text { kerja, kebiasaan } \\
\text { penggunaan } \\
\text { masker dan } \\
\text { kebiasaan } \\
\text { olahraga }\end{array}$ & $\begin{array}{l}\text { Tidak terdapat hubungan } \\
\text { antara kadar debu kapur } \\
\text { dengan status faal paru } \\
\text { dan variabel lama kerja, } \\
\text { masa kerja serta } \\
\text { kebiasaan penggunaan } \\
\text { masker memiliki } \\
\text { hubungan yang } \\
\text { bermakna dengan status } \\
\text { faal paru pada pekerja }\end{array}$ \\
\hline 16. & $\begin{array}{l}\text { Ahmad } \\
\text { Zaenal } \\
\text { Arifin, } \\
\text { Kresna } \\
\text { Oktafianto, } \\
\text { Ridho } \\
\text { Awanda, }\end{array}$ & $\begin{array}{l}\text { Untuk mengetahui } \\
\text { sebaran debu } \\
\text { kapur pada pabrik } \\
\text { kapur di daerah } \\
\text { Tuban }\end{array}$ & & $\begin{array}{l}\text { Menggunakan } \\
\text { model } \\
\text { Gaussian } \\
\text { Plume }\end{array}$ & $\begin{array}{l}\text { Variabel } \\
\text { penelitian yaitu } \\
\text { polutan udara } \\
\text { yang berada di } \\
\text { area pabrik kapur }\end{array}$ & $\begin{array}{l}\text { Diperoleh hasil terdapat } \\
\text { beberapa titik yang } \\
\text { terkena dampak polutan } \\
\text { dari aktivitas pabrik } \\
\text { kapur }\end{array}$ \\
\hline
\end{tabular}




\section{PEMBAHASAN}

Partikel debu kapur dengan kejadian Infeksi Saluran Pernapasan Akut (ISPA)

Pertambangan batu kapur merupakan salah satu industri yang mempunyai kadar polutan pencemar udara sangat berbahaya dan dapat menggangu kesehatan, terutama pada pekerjanya. ${ }^{9}$ Industri batu kapur telah mencemari udara dengan debu dan gas-gas hasil pembakaran. Bahan bakar yang digunakan dalam pembakaran batu kapur dapat berupa kayu bakar, oil sludge, dan sebagainya. Proses pembakaran yang menggunakan beragam macam bahan dinamakan dengan pembakaran biomassa. Menurut EPA tahun 2016 dari proses pembakaran biomassa dapat menghasilkan asap, dimana partikel debu yang berada pada asap akan menghasilkan bermacam polutan udara, salah satunya yaitu particulate matter. Particulate matter (PM) adalah partikel debu yang melayang di udara untuk jangka waktu yang lama. Partikel debu batu kapur dapat mengganggu kesehatan bila terhirup oleh manusia, antara lain dapat mengganggu pernafasan, seperti sesak nafas ataupun terjadinya pneumoconiosis. Efek utama debu kapur terhadap tenaga kerja berupa kelainan paru baik bersifat akut dan kronis, terganggunya fungsi fisiologis, iritasi mata, iritasi sensorik serta penimbunan bahan berbahaya dalam tubuh. Efek terhadap saluran pernapasan adalah terjadinya infeksi saluran pernapasan akut (ISPA). ${ }^{10}$

\section{Faktor risiko pekerja terhadap kejadian ISPA}

Kadar debu kapur yang dihasilkan dari proses produksi mencemari udara di lingkungan kerja. Kemudian kadar debu tersebut dapat terpapar ke pekerja di tempat kerja melalui inhalasi (debu masuk melalui pernapasan pekerja), debu yang masuk melalui pernapasan dapat dilawan oleh sistem pertahanan pada pernapasan. Namun dalam kondisi tertentu dapat mengakibatkan penyakit pada saluran pernapasan. Salah satu penyakit yang disebabkan oleh pajanan debu kapur adalah Infeksi Saluran Pernapasan Akut (ISPA). ${ }^{11}$ ISPA sendiri tidak hanya disebabkan oleh pajanan debu kapur saja, terdapat beberapa faktor risiko pekerja yang dapat meningkatkan atau menurunkan risiko terjadinya ISPA. Beberapa faktor risiko pekerja yang dapat menyebabkan terjadinya ISPA diperoleh dari beberapa hasil penelitian antara lain: usia, masa kerja, lama kerja (lama paparan), penggunaan alat pelindung diri (masker), riwayat penyakit dan kebiasaan merokok. ${ }^{12}$

\section{Usia}

Dari beberapa hasil penelitian menunjukkan bahwa usia pekerja yang semakin bertambah maka akan semakin banyak alveoli yang rusak dan daya tahan tubuh ikut menurun ditambah dengan menurunnya sistem pernapasan pada saat usia diatas 30 tahun. ${ }^{13}$ Oleh karena itu usia dapat dikatakan merupakan salah satu faktor risiko pada pekerja yang dapat meningkatkan kejadian infeksi saluran pernapasan akut (ISPA).

\section{Masa Kerja}

Dari beberapa hasil penelitian menunjukkan bahwa semakin lama seseorang dalam bekerja maka semakin banyak dia telah terpapar bahaya yang ditimbulkan oleh lingkungan kerja. Hal ini menunjukkan bahwasanya paparan debu yang ada di lingkungan kerja dan terpapar oleh pekerja dan kosentrasi yang tinggi serta masa kerja yang semakin lama maka akan dapat berdampak pada gangguan fungsi paru seseorang. ${ }^{14}$ Oleh karena itu pekerja dengan masa kerja lebih lama memiliki arti bahwa pekerja tersebut lebih lama terpajan debu dan miliki risiko untuk terkena ISPA lebih tinggi.

\section{Lama Kerja}

Dari beberapa hasil penelitian menunjukkan bahwa lamanya seseorang bekerja umumnya berkisar 6-8 jam dalam sehari. Apabila waktu kerja diperpanjang maka akan menimbulkan 
ketidakefisienan yang tinggi bahkan menimbulkan penyakit diakibatkan oleh lamanya terpajan polutan cukup lama di lingkungan kerja. ${ }^{15}$ Oleh karena itu variabel lama bekerja tidak merupakan faktor risiko yang secara langsung berhubungan dengan gangguan pernapasan, hal ini karena variabel lama bekerja tidak dapat berdiri sendiri untuk memengaruhi gangguan pernapasan, sehingga memerlukan variabel lain untuk bersama-sama memengaruhi gangguan pernapasan. ${ }^{14}$

\section{Penggunaan alat pelindung diri (masker)}

Penggunaan alat pelindung diri (masker) adalah salah satu cara untuk meminimalkan pajanan debu kapur di tempat kerja sehingga diharapkann dapat menurunkan risiko ISPA yang diakibatkan oleh pajanan debu. Dengan mengenakan masker, diharapkan pekerja melindungi dari kemungkinan terjadinya gangguan pernapasan akibat terpajan udara yang kadar debunya tinggi. Walaupun demikian, tidak ada jaminan bahwa dengan mengenakan masker, seorang pekerja di industri akan terhindar dari kemungkinan terjadinya gangguan pernapasan. Dari beberapa hasil penelitian menunjukkan bahwa pekerja yang bekerja di area dengan kadar debu tinggi dan tidak menggunakan alat pelindung diri maka dapat dipastikan akan terpapar dan berisiko terkena gangguan saluran pernapasan. Oleh karena itu dapat dikatakan penggunaan alat pelindung diri (masker) pada pekerja merupakan salah satu faktor risiko terjadinya infeksi saluran pernapasan akut (ISPA). ${ }^{16}$

\section{Kebiasaan Merokok}

Merokok merupakan salah satu faktor yang bermakna dalam kejadian ISPA. Asap samping rokok mempunyai efek toksik lebih buruk dari pada asap utama terutama dalam menimbulkan iritasi mukosa saluran napas dan meningkatkan kecenderungan untuk mendapatkan ISPA. Asap utama juga mengandung radikal bebas yang berperan dalam kerusakan jaringan. ${ }^{17}$ Dari hasil penelitian juga diperoleh bahwa kebiasaan merokok dapat meningkatkan risiko terjadinya ISPA sebanyak 2,2 kali. ${ }^{18}$

\section{Riwayat Penyakit}

Riwayat penyakit merupakan faktor yang dianggap juga sebagai pencetus timbulnya gangguan pernapasan. Pekerja yang pernah mengidap penyakit paru cenderung akan mengurangi ventilasi perfusi sehingga alveolus akan terlalu sedikit mengalami pertukaran udara. Akibatnya akan menurunkan kadar oksigen dalam darah. ${ }^{19}$ Banyak ahli berkeyakinan bahwa penyakit emfisema kronik, pneumonia, asma bronkiale, dan sianosis akan memperberat kejadian gangguan fungsi paru pada pekerja yang terpajan oleh debu organik dan anorganik. ${ }^{20}$ Oleh karena itu dapat dikatakan bahwa riwayat penyakit pernapasan juga dianggap sebagai faktor risiko timbulnnya atau penyebab yang memperparah gangguan saluran pernapasan atau infeksi saluran pernapasan akut (ISPA).

Faktor risiko dari masing-masing pekerja tersebut kemudian mempengaruhi terjadinya ISPA baik meningkatkan atau menurunkan risiko akibat pajanan debu kapur di tempat kerja.

\section{KESIMPULAN}

Berdasarkan hasil telaah dari 16 jurnal yang telah dilakukan, diperoleh bahwa faktor risiko pekerja yang paling dominan memiliki korelasi dan meningkatkan kejadian ISPA yaitu masa kerja, riwayat penyakit, usia, penggunaan alat pelindung diri (masker) dan kebiasaan merokok.

\section{DAFTAR PUSTAKA}

1. Suma'mur P. Higiene Perusahaan dan Kesehatan Kerja. Jakarta: CV Haji Mas Agung; 2014.

2. Kuswana. Ergonomi dan Kesehatan Keselamatan Kerja. PT. Remaja Rosdakarya; 2014.

3. Febri V. Analisis Gangguan Infeksi Saluran Pernafasan Akut Dan Hubungannya Dengan Lokasi Pertambangan di Gunung Kapur Puger Kabupaten Jember Sebagai Sumber Belajar Biologi. J Muhammadiyah Malang. 2020;

4. Rahayu Simanjuntak NS. Hubungan Antara Kadar Debu Batubara Total Dan Terhirup Serta Karakteristik Individu Dengan Gangguan Fungsi Paru Pada Pekerja Di Lokasi Coal Yard Pltu X 
Jepara. J Kesehat Masy Univ Diponegoro. 2013;2(2):18705.

5. Okoli C, Schabram K. Working Papers on Information Systems A Guide to Conducting a Systematic Literature Review of Information Systems Research. Work Pap Inf Syst. 2010;10(2010).

6. Lantong J, Asfian P, Erawan P. Faktor Yang Berhubungan Dengan Kejadian Ispa Pada Pekerja Penggilingan Padi Di Desa Wononggere Kecamatan Polinggona Kabupaten Kolaka Tahun 2016. J Ilm Mhs Kesehat Masy Unsyiah. 2017;2(6):184173.

7. Armaeni ED, Widajati N. Hubungan Paparan Debu Kapur Dengan Status Faal Paru Pada Pekerja Gamping. Indones J Occup Saf Heal. 2017;5(1):61.

8. Arifin AZ. SEBARAN DEBU JUBUNG PABRIK KAPUR. 2019;01(02):79-82.

9. Fevria R. Analisis kualitas udara di daerah penambangan batu kapur Tui Kota Padang Panjang. Eksakta. 2016;2(5):31-7.

10. Leni W. Infeksi Saluran Pernafasan Akut Pada Pekerja Penambang Kapur. J Stikes Karya Mitra Husada Kediri. 2018;

11. Yunus M, Raharjo W, Fitriangga A. Faktor-faktor yang berhubungan dengan kejadian infeksi saluran pernapasan akut ( ISPA ) pada pekerja PT . X Factors related to acute respiratory infection ( ARI) incidence among workers at PT . X. Kesehatan. 2020;6(1):21-30.

12. Suwanto YEP. Analisis Faktor Fisik Lingkungan dan Karakteristik Pekerja dengan Keluhan Pernapasan pada Pekerja di Industri Panci Aluminium. J Kesehat Lingkung. 2018;10(4):409-16.

13. Fuqoha I, Suwondo A, Jayanti S. Hubungan Paparan Debu Kayu Dengan Kejadian Infeksi Saluran Pernapasan Akut (Ispa) Pada Pekerja Mebel Di Pt.
$X$ Jepara. J Kesehat Masy. 2017;5(1):378-86.

14. Akili RH, Kolibu F, Tucunan AC, Lingkungan K, Masyarakat FK, Ratulangi US. Kejadian Penyakit Infeksi Saluran Pernapasan Akut pada Pekerja Tambang Kapur. Kes Mas J Fak Kesehat Masy Univ Ahmad Daulan. 2017;11(1):41-5.

15. Yudi S. Hubungan Antara Paparan Debu Dengan Derajat Obstruksi dan Derajat Restriksi Pada Penambang Kapur Tradisional di Dusun Koro Desa Pongpongan Kecamatan Merakurak Kabupaten Tuban. J Muhammadiyah Malang Univ. 2016;

16. Putra YE. Kayu Bakar Dalam Industri Pembakaran Genteng Diduga Sebagai Penyebab Infeksi Saluran Pernafasan Akut (Ispa). 2017;2(2):219-23.

17. Fahmita A. Hubungan Paparan PM2,5 Faktor Fisik Lingkungan, Karakteristik Individu, Keluhan Pernafasan dan Gangguan Faal Paru Pada Pekerja (Studi di Industri Pembakaran Batu Kapur CV. Indah Lestari Kecamatan Plumpang Kabupaten Tuban). J Univ Airlangga Surabaya. 2019;

18. Putra BH, Afriani R. Kajian Hubungan Masa Kerja, Pengetahuan, Kebiasaan Merokok, Dan Penggunaan Masker Dengan Gejala Penyakit Ispa Pada Pekerja Pabrik Batu Bata Manggis Gantiang Bukittinggi. Hum Care J. 2018;2(2):48-54.

19. Yunipah L. Faktor Karakteristik dan Lingkungan yang Berhubungan dengan Gangguan Fungsi Paru (Studi pada Masyarakat yang Terpapar Debu Batu Kapur di Desa Jatilaba Kabupaten Tegal). J Univ Muhammadiyah Semarang. 2016;

20. Widodo A. Hubungan Antara Lamanya Bekerja Sebagai Penambang Batu Kapur Dengan Nilai Vo2 Maks di Pertambangan Daerah Gunungkidul. J Univ Muhammadiyah Surakarta. 2017; 